\title{
Front Matter: Volume 8556
}

, "Front Matter: Volume 8556," Proc. SPIE 8556, Holography, Diffractive Optics, and Applications V, 855601 (26 November 2012); doi:

10.1117/12.2016776

SPIE. Event: Photonics Asia, 2012, Beijing, China 


\title{
Holography, Diffractive Optics, and Applications $V$
}

\author{
Yunlong Sheng \\ Chongxiu Yu \\ Linsen Chen \\ Editors
}

\section{5-7 November 2012 Beijing, China}

\author{
Sponsored by \\ SPIE \\ COS_Chinese Optical Society
}

\section{Cooperating Organizations}

Tsinghua University (China) • Peking University (China) • Zhejiang University (China) • Beijing Institute of Technology (China) • Beijing University of Posts and Telecommunications (China) • University of Science and Technology of China (China) • Tianjin University (China) • Nankai University (China) • Changchun University of Science and Technology (China) • University of Shanghai for Science and Technology (China) • Capital Normal University (China) • Huazhong University of Science and Technology (China) • Beijing Jiaotong University (China) • Shanghai Institute of Optics and Fine Mechanics (China) • Changchun Institute of Optics and Fine Mechanics (China) - Institute of Semiconductors (China) - Institute of Optics and Electronics (China) • Institute of Physics (China) • Shanghai Institute of Technical Physics (China) • China Instrument and Control Society (China) • Optoelectronics Technology Committee, COS (China) - SPIE National Committee in China (China) • Japan Optical Society (Japan) • Korea Optical Society (Korea, Republic of) • Australia Optical Society (Australia) • Singapore Optical Society (Singapore)

Supporting Organizations

CAST_China Association for Science and Technology (China)

NSFC-National Nature Science Foundation (China)

Published by

SPIE

\section{Volume 8556}


The papers included in this volume were part of the technical conference cited on the cover and title page. Papers were selected and subject to review by the editors and conference program committee. Some conference presentations may not be available for publication. The papers published in these proceedings reflect the work and thoughts of the authors and are published herein as submitted. The publisher is not responsible for the validity of the information or for any outcomes resulting from reliance thereon.

Please use the following format to cite material from this book:

Author(s), "Title of Paper," in Holography, Diffractive Optics, and Applications V, edited by Yunlong Sheng, Chongxiu Yu, Linsen Chen, Proceedings of SPIE Vol. 8556 (SPIE, Bellingham, WA, 2012) Article CID Number.

ISSN: 0277-786X

ISBN: 9780819493118

Published by

SPIE

P.O. Box 10, Bellingham, Washington 98227-0010 USA

Telephone +1 3606763290 (Pacific Time) · Fax +1 3606471445

SPIE.org

Copyright (C) 2012, Society of Photo-Optical Instrumentation Engineers.

Copying of material in this book for internal or personal use, or for the internal or personal use of specific clients, beyond the fair use provisions granted by the U.S. Copyright Law is authorized by SPIE subject to payment of copying fees. The Transactional Reporting Service base fee for this volume is $\$ 18.00$ per article (or portion thereof), which should be paid directly to the Copyright Clearance Center (CCC), 222 Rosewood Drive, Danvers, MA 01923. Payment may also be made electronically through CCC Online at copyright.com. Other copying for republication, resale, advertising or promotion, or any form of systematic or multiple reproduction of any material in this book is prohibited except with permission in writing from the publisher. The CCC fee code is 0277-786X/12/\$18.00.

Printed in the United States of America.

Publication of record for individual papers is online in the SPIE Digital Library.

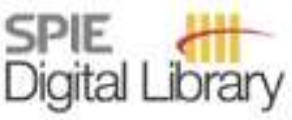

SPIEDigitalLibrary.org

Paper Numbering: Proceedings of SPIE follow an e-First publication model, with papers published first online and then in print and on CD-ROM. Papers are published as they are submitted and meet publication criteria. A unique, consistent, permanent citation identifier (CID) number is assigned to each article at the time of the first publication. Utilization of CIDs allows articles to be fully citable as soon as they are published online, and connects the same identifier to all online, print, and electronic versions of the publication. SPIE uses a six-digit CID article numbering system in which:

- The first four digits correspond to the SPIE volume number.

- The last two digits indicate publication order within the volume using a Base 36 numbering

system employing both numerals and letters. These two-number sets start with 00, 01, 02, 03, 04,

$05,06,07,08,09,0 A, 0 B \ldots$. 0Z, followed by 10-1Z, 20-2Z, etc.

The CID Number appears on each page of the manuscript. The complete citation is used on the first page, and an abbreviated version on subsequent pages. Numbers in the index correspond to the last two digits of the six-digit CID Number. 


\section{Contents}

ix Symposium Committees

xi Conference Committee

xiii Quantum dot lasers and relevant nanoheterostructures (Plenary Paper)

[8552-1]

\section{SESSION 1 3D DISPLAY I}

855602 Transparent 3D display for augmented reality (Invited Paper) [8556-1]

B. Lee, J. Hong, Seoul National Univ. (Korea, Republic of)

855603 Fourier holographic display system of three-dimensional images using phase-only spatial light modulator [8556-2]

H. Zhang, Y. Zhao, H. Gu, Q. Tan, L. Cao, G. Jin, Tsinghua Univ. (China)

855605 Comparative analysis on light field reconstruction characteristics of autostereoscopic three-dimensional display technologies (Invited Paper) [8556-3]

J. -H. Park, Chungbuk National Univ. (Korea, Republic of)

\section{SESSION 2 3D DISPLAY II}

855607 Binocular and multi-view parallax images acquisition for three dimensional stereoscopic displays [8556-6]

H. Ge, X. Sang, T. Zhao, J. Yuan, J. Leng, Beijing Univ. of Posts and Telecommunications (China); Y. Zhang, Minzu Univ. of China (China); B. Yan, Beijing Univ. of Posts and Telecommunications (China)

855608 An experimental study on the relationship between maximum disparity and comfort disparity in stereoscopic video [8556-8]

Z. Chen, J. Shi, Y. Tai, Yunnan Normal Univ. (China)

\section{SESSION $3 \quad$ TELECOMM APPLICATION}

8556 OA A novel super-orthogonal modulation scheme for high speed optical OFDM system [8556-10]

Q. Zhang, X. Xin, L. Zhang, Y. Wang, C. Yu, N. Meng, H. Wang, Beijing Univ. of Posts Communication (China) 
8556 OD Impact of surface waves on the electromagnetic enhancement by a metallic nano-cavity (Invited Paper) [8556-13]

H. Liu, Z. Zeng, Nankai Univ. (China)

8556 OE Enhanced subwavelength light spot of vertically tapered metallic aperture based on plasmonics [8556-15]

J.-B. Park, K. Kim, I.-M. Lee, D. Choi, B. Lee, Seoul National Univ. (Korea, Republic of)

8556 OF Theory on the quasi-cylindrical wave diffracted by a subwavelength metallic slit and its enhancement by surface plasmon resonance [8556-14]

Y. Gravel, Y. Sheng, Univ. Laval (Canada)

SESSION $5 \quad$ DIFFRACTION OF PLASMONIC STRUCTURE II

8556 OG Tunable nano-pattern generation based on surface plasmon polaritons (Invited Paper)

[8556-16]

C. Wang, F. Xu, Y. Lou, B. Cao, Soochow Univ. (China)

\section{SESSION 6 DIGITAL HOLOGRAPHY I}

8556 Ol Digital holographic display for a single user (Invited Paper) [8556-18]

J. Hahn, Kyungpook National Univ. (Korea, Republic of); H. Kim, Korea Univ. (Korea,

Republic of)

\section{SESSION 7 DIGITAL HOLOGRAPHY II}

8556 OK A JPEG-based enhanced compression algorithm of digital holograms [8556-21]

H. YU, Z. Zhang, J. Zhong, Jinan Univ. (China)

$8556 \mathrm{OL} \quad$ Effect of phase-shift step on hologram reconstruction in Fresnel incoherent correlation holography [8556-22]

H. Chen, Y. Wan, T. Man, Z. Jiang, D. Wang, Beijing Univ. of Technology (China)

8556 ON Detection of silver ions induced morphological changes on $E$. coli membrane using digital holographic microscopy [8556-24]

F. Borji, A. Mohebi, Univ. of Zanjan (Iran, Islamic Republic of); A.-R. Moradi, Univ. of Zanjan (Iran, Islamic Republic of) and Optics and Photonics Research Ctr. (Iran, Islamic Republic

of); S. Tavaddod, TarbiatModares Univ. (Iran, Islamic Republic of)

\section{SESSION 8 ADVANCED DIFFRACTIVE ELEMENTS}

855600 Slanted volume holographic gratings design based on rigorous coupled-wave analysis (Invited Paper) [8556-28]

T. Li, L. Cao, Q. He, G. Jin, Tsinghua Univ. (China) 
8556 OP A parameters study of the multi-plane diffraction iterative algorithm of the single-beam phase retrieval [8556-27]

Y. Sun, Z. Zhang, J. Zhong, Jinan Univ. (China)

8556 OR Fast generation of hologram from range camera images based on the sub-lines and holographic interpolation (Invited Paper) [8556-29]

P. Tsang, W. C. Situ, W.-K. Cheung, City Univ. of Hong Kong (Hong Kong, China);

T.-C. Poon, Virginia Polytechnic Institute and State Univ. (United States) and Shanghai Institute of Optics and Fine Mechanics (China); C. Zhou, Shanghai Institute of Optics and Fine Mechanics (China)

8556 OT High-efficient design method of large diffractive optical elements by vectorial field analysis based on boundary element method (Invited Paper) [8556-26]

J. Sugisaka, T. Yatagai, Utsunomiya Univ. (Japan)

\section{SESSION 9 NANO MEASUREMENT AND FABRICATION}

8556 OU Dynamic holographic interferometry with matrix LC modulator (Invited Paper) [8556-31] S. A. Pulkin, Saint Petersburg State Univ. (Russian Federation); V. Y. Venediktov, Saint Petersburg State Univ. (Russian Federation) and Saint-Petersburg State Electrotechnical Institute (Russian Federation) and Vavilov State Optical Institute (Russian Federation); V. Ivanov, V. I. Korotkov, I. M. Pasechnik, Saint Petersburg State Univ. (Russian Federation); A. A. Sevrygin, Saint Petersburg State Electrotechnical Univ. (Russian Federation); M. A. Solov'ev, Vavilov State Optical Institute (Russian Federation)

$8556 \mathrm{OV}$ The influence of modified squeezing ratio on the birefringence characteristics of photonic crystal fibers [8556-34]

P. Song, Univ. of Jinan (China)

8556 OW 3D measurement system with two detecting channels using structured light [8556-33]

S. Wei, C. Zhou, S. Wang, Shanghai Institute of Optics and Fine Mechanics (China)

\section{SESSION 10 APPLICATIONS}

8556 OY Beam splitters of metal-dielectric reflective gratings [8556-36]

A. Hu, C. Zhou, H. Cao, J. Wu, J. Wei, Shanghai Institute of Optics and Fine Mechanics (China)

$85560 Z$ Three-dimensional optical techniques using Dammann gratings (Invited Paper) [8556-35] C. Zhou, J. Yu, S. Wang, S. Wei, Shanghai Institute of Optics and Fine Mechanics (China)

855610 The study on the focusing property of the VLS grating with different types of beams [8556-37]

C. Wang, W. Zhang, Y. Gao, Guangxi Univ. (China)

855611 Absorption enhancement in thin-film solar cell using grating structure [8556-38] J. Wu, C. Zhou, H. Cao, A. Hu, W. Jia, Shanghai Institute of Optics and Fine Mechanics (China) 
855612 Calibration and pre-compensation of direct laser writing system [8556-40]

F. Zhu, C. Zhou, J. Ma, Shanghai Institute of Optics and Fine Mechanics (China)

855613 Quantitative evaluation of spatial phase light modulator characteristics in Fresnel incoherent correlation holography [8556-41]

T. Man, Y. Wan, H. Chen, Z. Jiang, D. Wang, Beijing Univ. of Technology (China)

855615 An optically addressed liquid crystal light valve with high transmittance [8556-42]

D. Huang, W. Fan, X. Li, Z. Lin, Shanghai Institute of Optics and Fine Mechanics (China)

855616 Tunable photonic structures from liquid crystal elastomers [8556-43]

M. Gregorc, Univ. of Ljubljana (Slovenia); H. Li, Nankai Univ. (China); V. Domenici, Univ. degli studi di Pisa (Italy); I. Drevenšek-Olenik, Univ. of Ljubljana (Slovenia) and J. Stefan Institute (Slovenia)

855617 Optical path difference characteristics of the fluorescence holographic system [8556-39] X. Lai, S. Zeng, Britton Chance Ctr. for Biomedical Photonics (China) and Huazhong Univ. of Science and Technology (China)

\section{POSTER SESSION}

855619 Speckle noise reduction in digital holography due to angular diversity by spatial light modulator [8556-49]

P. Meng, D. Wang, L. Rong, Y. Wang, Beijing Univ. of Technology (China)

8556 1A Iterative partial quantization method for the error reduction of low-quantized kinoforms [8556-50]

S. Yang, S. Serikawa, Kyushu Institute of Technology (Japan)

8556 1C Computer simulation and optimization design of the holographic photonic crystal template fabrication process [8556-55]

Y. Liu, Academy of Armored Force Engineering (China)

8556 1D Numerical simulation of polarization dependent characteristics of the structured thin-films phase grating [8556-45]

Y. Y. Li, C. Hu, Y. C. Wu, H. H. Feng, J. J. Chen, Wenzhou Medical College (China)

8556 IF Design and Fabrication of nanowire-grid polarizer in near-infrared broadband [8556-60] Q. Jin, Q. Liu, J. Wu, Y. Cheng, Soochow Univ. (China)

8556 1G Phase imaging for photorefractive holographic gratings with dual-wavelength digital holography [8556-61]

Z. Gao, Z. Jiang, Y. Wang, J. Wu, Y. Wang, Beijing Univ. of Technology (China)

$85561 \mathrm{H}$ A novel iterative computation algorithm for Kinoform of 3D object [8556-46]

X. Jiang, P. Chuang, X. Wang, Y. Zong, Academy of Armored Force Engineering (China) 
$85561 \mathrm{~K}$ Experiment study on measurement of the optical fiber refractive index based on digital holography [8556-68]

D. Wang, Z. Chang, S. Huang, Shanghai Univ. (China)

$8556 \mathrm{lL} \quad$ Factors of influencing the value of $w$ in the bi-grating diffraction imaging equation [8556-69]

W. Zhang, F. Zhu, C. Wang, Y. Gao, L. Liu, Guangxi Univ. (China)

8556 1M Electro-holography display using computer generated hologram of 3D objects based on projection spectra [8556-70]

S. Huang, D. Wang, C. He, Shanghai Univ. (China)

8556 iN Holographic two-dimensional photonic crystal of LED decorative illumination [8556-72]

G. Li, Y. Zheng, Y. Qiu, A. Huang, Fujian Normal Univ. (China)

855610 Theoretical analysis of volume moiré tomography based on double orthogonal gratings for real 3D flow fields diagnosis [8556-73]

N. Sun, Y. Song, J. Wang, Z. Li, A. He, Nanjing Univ. of Science and Technology (China)

$85561 \mathrm{P} \quad$ A novel 2D wavelength-time chaos code in optical CDMA system [8556-74]

Q. Zhang, X. Xin, Y. Wang, L. Zhang, C. Yu, N. Meng, H. Wang, Beijing Univ. of Posts and Telecommunications (China)

$85561 Q$ Defect mode in a one-dimensional photonic crystal with a dielectric-superconducting pair defect [8556-53]

J. Wu, J. Gao, Shandong Univ. of Technology (China)

8556 IR Effective design of diffractive optical elements for beam splitting with SA algorithm [8556-54]

H. Pang, Institute of Optics and Electronics (China) and Univ. of Electronic Science and Technology of China (China); S. Yin, Chongqing Institute of Green and Intelligent Technology (China); Q. Deng, Institute of Optics and Electronics (China); Y. Fu, Univ. of Electronic Science and Technology of China (China); C. Du, Chongqing Institute of Green and Intelligent Technology (China)

8556 is Improving the phase measurement by the apodization filter in the digital holography [8556-62]

S. Chang, D. Wang, Y. Wang, J. Zhao, L. Rong, Beijing Univ. of Technology (China)

8556 1T Rectification of gridline structure in integral image using radon transform and perspective transformation [8556-63]

B. Wang, Y. Song, A. He, Nanjing Univ. of Science and Technology (China)

$85561 \mathrm{U}$ Study on effects of organic solvents on Hela cells by digital holography [8556-65]

L. Ouyang, D. Wang, Y. Wang, X. Wang, Beijing Univ. of Technology (China); L. Marx,

Beijing Univ. of Technology (China) and Graz Univ. of Technology (Austria) 
8556 IV Iterative phase difference constraint method for the speckle elimination of kinoforms [8556-56]

T. Hora, S. Yang, S. Serikawa, Kyushu Institute of Technology (Japan)

Author Index

viii

Proc. of SPIE Vol. $8556855601-8$

Downloaded From: https://www.spiedigitallibrary.org/conference-proceedings-of-spie on 26 Apr 2023 Terms of Use: https://www.spiedigitallibrary.org/terms-of-use 


\title{
Symposium Committees
}

\author{
General Chairs \\ Eustace L. Dereniak, College of Optical Sciences, The University of \\ Arizona (United States) \\ Bingkun Zhou, Tsinghua University (China)
}

General Cochairs

Arthur Chiou, National Yang-Ming University (Taiwan, China)

Zhizhan Xu, Shanghai Institute of Optics and Fine Mechanics (China)

Jianlin Cao, China Ministry of Science and Technology (China)

Junhao Chu, Shanghai Institute of Technical Physics (China)

Technical Program Chairs

Songlin Zhuang, Shanghai University of Science and Technology (China)

Xingde Li, Johns Hopkins University (United States)

Technical Program Cochairs

Qiming Wang, Institute of Semiconductors (China)

Xu Liu, Zhejiang University (China)

Daoyin Yu, Tianjin University (China)

Qihuang Gong, Peking University (China)

Tianchu Li, National Institute of Metrology (China)

Wei Huang, Nanjing University of Posts and Telecommunications (China)

Local Organizing Committee Chair

Guangcan Guo, University of Science and Technology of China (China) 
Local Organizing Committee Cochairs

Guoqiang Ni, Beijing Institute of Technology (China)

Shusen Xie, Fujian Normal University (China)

Xiaomin Ren, Beijing University of Posts and Telecommunications (China)

Ying Gu, PLA General Hospital (China)

Huilin Jiang, Changchun University of Science and Technology (China)

General Secretary

Qihuang Gong, Peking University (China)

Local Organizing Committee

Yan Li, Chinese Optical Society/Peking University (China)

Zhiping Zhou, Peking University (China)

Changhe Zhou, Shanghai Institute of Optics and Fine Mechanics (China)

Qingming Luo, Huazhong University of Science and Technology (China)

Chongxiu Yu, Beijing University of Posts and Telecommunications (China)

Hongda Chen, Institute of Semiconductors (China)

Yongtian Wang, Beijing Institute of Technology (China)

Yiping Cui, Southeast University (China)

Xuping Zhang, Nanjing University (China)

Feijun Song, Daheng Corporation (China)

Cunlin Zhang, Capital Normal University (China)

Yanting Lu, Nanjing University (China)

Yuejin Zhao, Beijing Institute of Technology (China)

Chunqing Gao, Beijing Institute of Technology (China)

Tiegen Liu, Tianjin University (China)

Xiaocong Yuan, Nankai University (China)

Weimin Chen, Chongqing University (China)

Zhongwei Fan, Academy of Optoelectronics (China)

Hanyi Zhang, Tsinghua University (China)

Lan Wu, Zhejiang University (China)

Yongsheng Zhang, University of Science and Technology of China (China)

Hong Yang, Peking University (China)

Xiaoying Li, Tianjin University (China)

Lin Zhai, Chinese Optical Society (China) 


\title{
Conference Committee
}

\author{
Conference Chairs
}

Yunlong Sheng, University Laval (Canada)

Chongxiu Yu, Beijing University of Posts and Telecommunications (China)

Linsen Chen, Soochow University (China)

\section{Conference Program Committee}

Chunlei Du, Institute of Optics and Electronics (China)

Min Gu, Swinburne University of Technology (Australia)

An-zhi He, Nanjing University of Science and Technology (China)

Dahsiung Hsu, Beijing University of Posts and Telecommunications (China)

Byoungho Lee, Seoul National University (Korea, Republic of)

Junchang Li, Kunming University of Science and Technology (China)

Ai-Qun Liu, Nanyang Technological University (Singapore)

Dahe Liu, Beijing Normal University (China)

Hai Ming, University of Science and Technology of China (China)

Ting-Chung Poon, Virginia Polytechnic Institute and State University (United States)

Ching-Cherng Sun, National Central University (Taiwan)

Toyohiko Yatagai, Utsunomiya University (Japan)

Baoli Yao, Xi'an Institute of Optics and Precision Mechanics (China)

Xiaocong Yuan, Nankai University (China)

Jianlin Zhao, Northwestern Polytechnical University (China)

Changhe Zhou, Shanghai Institute of Optics and Fine Mechanics

(China)

\section{Session Chairs}

1 3D Display I

Yunlong Sheng, University Laval (Canada)

2 3D Display II

Chongxiu Yu, Beijing University of Posts and Telecommunications (China)

3 Telecomm Application

Chongxiu Yu, Beijing University of Posts and Telecommunications (China) 
4 Diffraction of Plasmonic Structure I

Xiaocong Yuan, Nankai University (China)

5 Diffraction of Plasmonic Structure II

Byoungho Lee, Seoul National University (Korea, Republic of)

6 Digital Holography I

Chinhua Wang, Soochow University (China)

7 Digital Holography II

Chinhua Wang, Soochow University (China)

8 Advanced Diffractive Elements

Changhe Zhou, Shanghai Institute of Optics and Fine Mechanics (China)

9 Nano Measurement and Fabrication

Peter W. M. Tsang, City University of Hong Kong (Hong Kong, China)

10 Applications

Baoli Yao, Xi'an Institute of Optics and Precision Mechanics (China)

11 Devices and Fabrication

Dayong Wang, Beijing University of Technology (China) 